\title{
BAHASA MANDARIN DALAM ERA INDUSTRI 4.0 DAN ERA MASYARAKAT 5.0: IMPLEMENTASI KURIKULUM MERDEKA BELAJAR
}

\author{
Hermina Sutami \\ Universitas Indonesia
}

\begin{abstract}
Abstrak
Dunia tidak hanya memasuki tahap revolusi industri 4.0 saja yang memunculkan apa yang dinamakan kecerdasan buatan (artificial intelligence). Mayumi Fukuyama dari Jepang telah mencanangkan adanya revolusi sosial 5.0 yang berbicara tentang pemanfaatan teknologi digital dalam kehidupan manusia. Kedua jenis revolusi itu memiliki dampak terhadap pengajaran Bahasa Mandarin dalam penerapan Kurikulum Merdeka Belajar. Masalah yang diangkat adalah apa sumbangan pengajaran Bahasa Mandarin dalam mengantisipasi perkembangan teknologi digital di bidang bisnis agar tidak terjadi kesenjangan sosial. Bagaimana bentuk kurikulum yang tuntutannya semakin luas, tetapi waktu belajar semakin dikurangi? Tantangan apa yang dihadapi oleh prodi agar dapat memenuhi tuntutan pasar? Makalah ini bertujuan memberi pandangan dan masukan kepada perguruan tinggi (PT) agar menghasilkan lulusan yang dapat bersaing di bidang bisnis, tetapi tetap manusiawi dalam berinteraksi dengan manusia lain.
\end{abstract}

Kata Kunci : kurikulum, merdeka belajar, revolusi industri, bahasa mandarin

\section{A. PENDAHULUAN}

Kita sudah tiba pada Era Industri 4.0. Semua bidang harus tanggap dengan perkembangan teknologi digital ini, termasuk pengajaran Bahasa Mandarin di Indonesia. Perkembangan revolusi industri 4.0 ini tidak boleh membuat manusia bergantung pada alatalat teknologi yang canggih itu. Alat adalah benda mati yang harus dikendalikan oleh manusia. Jack $\mathrm{Ma}$ (pendiri Alibaba Group) berpendapat bidang pendidikan harus mengadakan perubahan, yakni menanamkan soft skills. Alat berupa perangkat mesin tidak memiliki perasaan (emosi, rasa estetika), keyakinan terhadap suatu keputusan, nilai-nilai berperilaku seperti peduli terhadap sesama manusia, berpikir dan kerja sama jika tidak diprogram (Sutami 2019), karena itu peran manusia tetap diperlukan.

Kemajuan teknologi membuat orang banyak menghabiskan waktu dengan komputer atau gawai, terutama kaum mileneal. Mereka kurang berinteraksi dengan anggota keluarga dan teman secara verbal. Mereka berinteraksi dengan alat-alat digital berupa komputer dan gawai, ditambah lagi dengan adanya warung internet (warnet) yang membuat mereka tidak memerlukan manusia lain. Hal ini diantisipasi oleh Jepang dengan mencanangkan konsep revolusi sosial atau revolusi masyarakat 5.0.

Revolusi industri 4.0 dan sosial 5.0 ini berdampak pada pengajaran Bahasa Mandarin yang akan menerapkan Kurikulum Merdeka Belajar. Apa sumbangan pengajaran Bahasa Mandarin dalam mengantisipasi perkembangan teknologi digital di bidang bisnis. Bagaimana menyeimbangkan kemajuan teknologi digital agar tidak terjadi kesenjangan sosial? Mengingat APSMI berada di dunia pendidikan, kita hendaknya memikirkan kompetensi lulusan seperti apa yang dapat memenuhi tuntutan kemajuan industri 4.0 tetapi tetap berpusat pada manusia? Apakah dampak revolusi sosial 5.0 juga sudah hadir di tengah masyarakat Indonesia? Makalah ini bertujuan memberi pandangan dan masukan kepada 
perguruan tinggi (PT) agar menghasilkan lulusan yang dapat bersaing di bidang bisnis, tetapi tetap manusiawi dalam berinteraksi dengan manusia lain.

\section{B. ERA REVOLUSI INDUSTRI 4.0}

Era revolusi industri 4.0 dihadapi setelah melewati era revolusi industri tahap 1.0, 2.0, dan 3.0. Pada tahap 4.0 muncul istilah disrupsi (disruption) yang diterjemahkan menjadi 'gangguan' atau 'kekacauan'. KBBI daring menerjemahkan menjadi 'hal tercerabut dari akarnya'. Jika digunakan kata gangguan atau kekacauan, kata itu berkonotasi negatif dan kurang "mengena". Kita merasakan kemudahan berkomunikasi tanpa batas ruang dan waktu melalui internet, sekalipun terjadi kesulitan menyesuaikan diri dan belajar hal baruterutama bagi generasi tua. Dengan menggunakan kata disrupsi yang tidak berasal dari Bahasa Indonesia, kita berusaha mengaburkan konotasi negatif itu dan mengambil segi positif dari perkembangan teknologi ini (Sutami 2019). Pada era disrupsi ini, kita harus tanggap, kreatif, dan inovatif agar tidak tenggelam dalam arus perkembangan CPS (Cyber physical system) yang menyebarkan informasi seperti sebuah jaringan. Penyebaran informasi melalui CPS yang tidak hanya melalui komputer, tetapi sudah merambah ke gawai atau ponsel yang memiliki fasilitas internet.

Perguruan tinggi sudah mengantisipasi revolusi industri 4.0 dari segi administratif dengan menjalankan kegiatan komputerisasi dalam pelayanan kepada mahasiswa. Begitu pula di bidang pengajaran banyak digunakan akses internet dalam mencari data, informasi, sumber bacaan. Di masa pandemi covid 19 ini kemajuan teknologi digital sangat berarti karena kegiatan perkuliahan, seminar, penelitian semuanya dilakukan tanpa tatap muka lagi. Keuntungan yang diperoleh dari industri 4.0 ini antara lain laju industri dipercepat karena komunikasi menjadi mudah, memakai alat-alat yang terkomputerisasi. Dengan cara ini muncul ide-ide baru dan kreatif guna memenuhi selera dan kebutuhan konsumen. Di internet banyak kita temukan tawaran kursus, kuliah secara daring. Akibatnya, PT harus menyesuaikan diri dengan menawarkan kuliah daring yang dapat menjangkau mahasiswa di mana pun mereka berada.

Dampak revolusi industri 4.0 ini sangat terasa di bidang bisnis, bagaimana tiba-tiba bermunculan ojek dan taksi daring yang membuat ojek dan taksi tradisional kelimpungan. Kegiatan bisnis yang offline atau luring (luar jaringan) digantikan oleh online atau daring (dalam jaringan) yang memerlukan kecanggihan alat digital. Sudah kita saksikan bagaimana ponsel blackberry dikalahkan oleh ponsel android yang mempunyai applikasi whatsapp sehingga orang dari belahan dunia manapun dapat saling berkomunikasi tanpa kendala jarak dan waktu. Itulah kemajuan yang dicapai dalam revolusi 4.0 ini, informasi tersebar dalam sekejap. Penerima informasi harus dapat menimbang berita mana yang bisa dipercaya atau berita bohong. Bisnis daring berkembang pesat karena orang tidak perlu lagi pergi ke toko, cukup dengan gawai saja. Akibatnya banyak toko bangkrut karena kehilangan pelanggan yang berkunjung ke tokonya, termasuk toko buku. Percetakan mengalami kerugian karena orang lebih suka membaca buku elektronik atau e-book karena kepraktisannya. Buku setebal apa pun dapat disimpan di sebuah alat yang tipis yang berukuran seperempat kertas kwarto itu. Begitu pula betapa sepinya toko foto kopi karena pelanggannya menjadi sangat berkurang.

Akibat dari revolusi ini adalah banyak tenaga yang tidak dibutuhkan sehingga terjadilah pengangguran. Kejadian serupa terjadi saat revolusi industri 1.0 di Britania Raya ${ }^{1}$ tahun 1750-1850. Revolusi industri ini kemudian menyebar ke Eropa Barat, Amerika Utara 
dan seluruh dunia. Bidang pekerjaan lama di bidang pertanian seperti membajak dengan hewan tergantikan oleh mesin. Muncul berjenis-jenis mesin yang dapat bergerak cepat dalam menghasilkan produk dengan waktu singkat. Pada era 2.0 terjadi produksi massal, listrik menjadi andalan utama dalam industri. Era industri 3.0 ditandai dengan munculnya komputer yang dilanjutkan dengan perkembangan yang lebih canggih pada era 4.0. Pada setiap era ada bidang pekerjaan yang hilang, tetapi bermunculan yang baru. Masyarakat harus cepat dan tanggap menghadapi situasi ini karena ini merupakan pergerakan pasar aktif.

Dalam era industri 4.0 muncul apa dinamakan kecerdasan buatan (artificial Intelligence). Konsep kecerdasan buatan ini meniru kecerdasan manusia yang dapat berpikir dan bertindak seperti manusia secara rasional. Kamera pada gawai dapat menyesuaikan dirinya dengan cahaya yang dihadapinya, antara lain merupakan contoh kecerdasan buatan. Era industri ini telah memberikan kemudahan dalam bertindak, berkomunikasi dan berbisnis secara digital.

\section{ERA MASYARAKAT 5.0}

Era Masyarakat 5.0 ini sebenarnya juga merupakan sebuah revolusi yang berhubungan dengan manusia . Jika industri 4.0 berbicara tentang penemuan teknologi untuk industri, revolusi masyarakat 5.0 berbicara tentang pemanfaatan teknologi digital untuk kehidupan manusia, demikian pendapat Mayumi Fukuyama dalam artikelnya di laman Japan Economic-Foundation. Pemrakarsa konsep masyarakat 5.0 adalah Jepang. Karena jumlah penduduk usia produktif di Jepang semakin menurun, mereka perlu memanfaatkan kemajuan teknologi digital ini untuk menggantikan tenaga manusia.

Revolusi masyarakat 5.0 ini tidak terlepas dari revolusi industri 4.0. Silakan memperhatikan gambar berikut ini (https://www.puskomedia.id/masyarakat-5-0, diunduh 18 Oktober 2020).

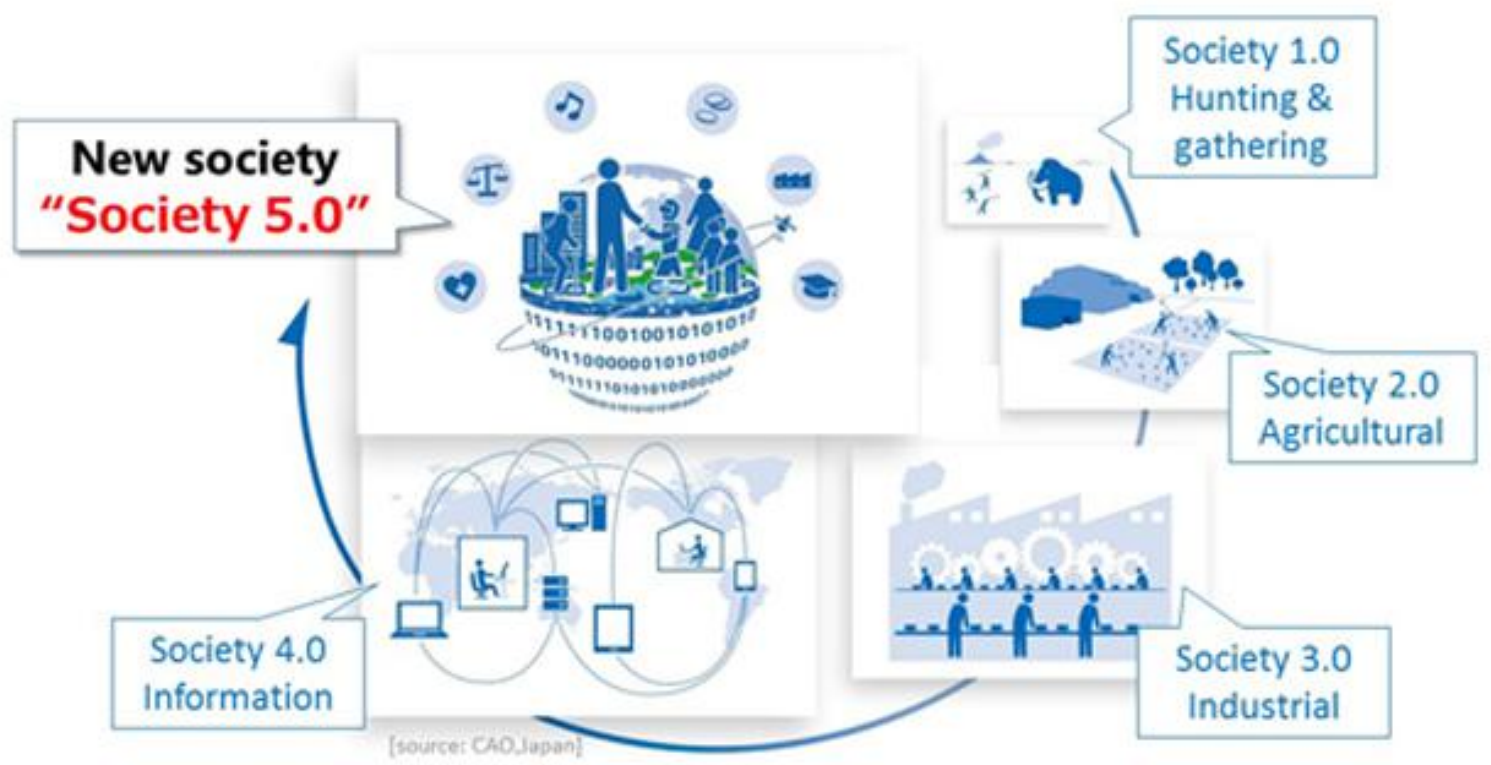

Pada tahap awal (revolusi sosial 1.0) manusia mengalami perubahan kehidupan dari sebelumnya hidup berburu dan mengumpulkan hasil berburu guna melanjutkan hidup dalam komunitasnya. Ketika kesadaran dan kecerdasan bertambah, mereka mulai 
memikirkan perlu kehidupan yang lebih mapan dengan hasil yang lebih mantap yakni dengan bercocok tanam (revolusi sosial 2.0). Ketika terjadi terjadi revolusi agraria (revolusi industri 1.0), lahan pertanian diubah menjadi peternakan domba karena industri wol sedang berkembang. Petani yang bidang pekerjaannya di sawah menjadi tersingkir. Mereka pindah ke kota untuk menjadi buruh pabrik. Arus urbanisasi sangat tinggi sehingga terjadi kelebihan tenaga kerja yang mengakibatkan upah tenaga kerja menjadi rendah. Di sinilah timbul perubahan tatanan sosial. Muncul kelas buruh dan kelas pengusaha. Karena jumlah buruh banyak, upah rendah, timbullah kemiskinan yang berdampak kepada masalah kesehatan. Pengalihan dari perekonomian berbasis pertanian ke manufaktur (perpabrikan) memberi dampak pada kehidupan sosial, budaya masyarakat (Sutami 2019). Dengan demikian terjadi revolusi masyarakat 3.0.

Ilmu pengetahuan pun semakin berkembang, manusia berusaha mencari hal yang "lebih" daripada apa yang sudah ada. Awal dari kemudahan berkomunikasi ditandai dengan diciptakannya komputer yang menggantikan mesin tik. Komputer terus dikembangkan sampai pada kehadiran internet, telepon seluler yang memudahkan penggunanya mengakses informasi. Revolusi industri 4.0 berimbas kepada adanya revolusi masyarakat 4.0 . Nasrul Helmi (2019) mengatakan

"ada ledakan besar dalam dunia teknologi yang secara radikal mengubah cara manusia hidup dan bekerja [...] memberi peluang adanya efisien dan inovasi besarbesaran $[. . .]^{\prime \prime}$

Kita ketahui bahwa pemakaian robot sudah dilakukan untuk mengantikan tenaga manusia, misalnya di rumah sakit, karena robot tidak dapat tertular penyakit seperti manusia. Beberapa pabrik Indonesia sudah menggunakan robot dalam merakit mobil, menggunakan kendaraan otomatis untuk membawa barang ke gudang sehingga terjadi penghematan tenaga, biaya. Kecerdasan buatan (artificial intelligence) seperti robot, mobil tanpa supir, drone digunakan untuk memudahkan kehidupan manusia di bidang ekonomi, pendidikan, sosial, kesehatan.

Di Jepang kecerdasan buatan ini dapat membantu orang yang hidup di daerah terpencil agar mudah mendapatkan akses transportasi ke tempat yang dituju. Indonesia mencanangkan desa sebagai kunci sukses menuju masyarakat 5.0. Puskomedia sebagai perusahaan yang cara kerjanya didasarkan pada laboratorium digital secara kreatif memecahkan masalah dengan menggunakan TIK (teknologi informasi komunikasi atau Information Communications Technology). Panda SID (Sistem Informasi Desa) adalah satu programnya untuk memajukan desa melalui pemanfaatan teknologi. Seberapa jauh kemajuan yang dicapai oleh desa yang mendapatkan program Panda SID ini, tidak akan diuraikan di sini.

Bagaimana dengan dunia pendidikan, khususnya pengajaran Bahasa Mandarin di Indonesia dengan Kurikulum Merdeka Belajarnya? Apa yang dapat dilakukan melalui pengajaran Bahasa Mandarin dalam menghadapi Era Industri 4.0 dan Era Masyarakat 5.0 ini? Makalah ini mencoba memberikan pandangan-pandangan yang diharapkan dapat membangkitkan pemikiran baru bagi PT.-

\section{TANTANGAN BAGI PERGURUAN TINGGI}

Ada beberapa tantangan yang dihadapi PT pada era Revolusi Industri 4.0. Revolusi Masyarakat 5.0. Di Indonesia revolusi 5.0 tampaknya belum menunjukkan dampaknya 
seperti di Jepang. Memang, robot sudah mulai digunakan di perusahaan, tetapi bukan karena berkurangnya tenaga produktif. Bagi Indonesia dewasa ini mendidik tenaga manusia yang kompeten menggunakan teknologi digital lebih urgen. Tenaga siap pakai adalah salah satu tujuan PT menghasilkan lulusannya seperti tercermin dalam Kurikulum Merdeka Belajar yang berbasiskan konsep luaran (Outcome-based concept). Dalam konsep itu, Capaian Pembelajaran (CP) merupakan tujuan akhir dari pembelajaran setiap mata kuliah. Pendidikan demikian disebut Pendidikan Berbasiskan Luaran (Outcome-based Education/OBE). Luaran dari OBE adalah keterserapan lulusan di dunia kerja dengan mutu lulusan yang tinggi. Keterserapan lulusan dengan mutu tinggi mengacu kepada kontribusi apa yang dapat diberikan oleh perguruan tinggi kepada masyarakat.

Kurikulum Merdeka Belajar yang berbasiskan luaran berupa CP merupakan jawaban KEMENRISTEKDIKTI terhadap visi misi Presiden Joko Widodo. Presiden menghendaki perguruan tinggi mampu menciptakan SDM yang lebih unggul sehubungan dengan terjadinya Revolusi Industri 4.0. Pada kurikulum tersebut, Merdeka Belajar berada di lingkungan Kampus Merdeka dengan gagasan Kemerdekaan Belajar. Mengenai hal itu, Menteri Menteri Pendidikan dan Kebudayaan, Nadiem Anwar Makarim, dalam Buku Saku Panduan Merdeka Belajar Kampus Merdeka menyatakan:

"Memberi kebebasan dan otonomi kepada lembaga pendidikan, dan merdeka dari birokratisasi, dosen dibebaskan dari birokrasi yang berbelit serta mahasiswa diberikan kebebasan untuk memilih bidang yang mereka sukai."

Inilah tantangan yang dihadapi oleh perguruan tinggi. Bagaimana menghasilkan lulusan siap pakai dengan mutu tinggi yang bisa diserap oleh perusahaan dalam delapan semester? Sebuah tugas yang berat, terutama untuk program studi yang mengajarkan Bahasa Mandarin sebagai kemahiran utama. Perancang kurikulum harus mengarahkan tujuan pengajaran pada OBE dengan CP yang jelas dari setiap MK (Mata Kuliah). Adapun Kompetensi lulusan PT adalah (1) melek teknologi digital (2) memenuhi kebutuhan pasar nasional \& internasional (3) memberi sumbangan pada kehidupan masyarakat dengan menyeimbangkan kemajuan teknologi digital dengan kebutuhan masyarakat Indonesia.

Kebebasan diberikan kepada PT, termasuk mahasiswa, seperti yang disebutkan di atas merupakan kebijakan baru. Mahasiswa diberi hak memilih bidang yang disukai di luar prodinya (program studi) atau di luar perguruan tingginya dengan jumlah SKS (40\%). Di samping itu, mahasiswa juga wajib melakukan kegiatan magang yang dilakukan di luar kampus. Itu semua diatur oleh Permendikbud Nomor 3 Tahun 2020 tentang Standar Nasional Pendidikan Tinggi.

Ada kebebasan yang diberikan kepada mahasiswa, tetapi mereka dituntut untuk memiliki kreativitas, rasa ingin tahu, tahan banting, empati, berpikir kritis, mampu menyelesaikan masalah, percaya diri, mampu kerja sama, mau belajar. Mereka harus menguasai berbagai ilmu yang mata kuliahnya dapat diambil di luar prodi dan luar universitasnya.

Tugas PT melalui prodi-prodinya adalah memberikan ilmu yang siap pakai di dunia kerja, mencari cara pengajaran seefektif mungkin untuk mentransfer ilmu dengan berdasarkan pembelajaran berpusat pada pembelajar (student centered learning). Di samping itu, PT harus mencari mitrakerja agar supaya mahasiswanya dapat melakukan praktek kerja atau magang di tempat mitrakerja tersebut. Magang merupakan salah satu persyaratan dalam Kurikulum Merdeka Belajar ini. 


\section{E. TANTANGAN BAGI PROGRAM STUDI MANDARIN/TIONGKOK/CHINA/SINOLOGI}

Era Industri 4.0 menyangkut beberapa unsur PT seperti dosen, mahasiswa, kurikulum dan tenaga administratif. Tenaga administratif di PT sudah dilatih menggunakan peralatan yang memanfaatkan teknologi dengan sistem komputerisasi dan jaringan internetnya. Keempat unsur ini mau tidak mau sudah harus berada dalam sistem fisikal cyber, jika tidak mau tersaingi oleh PT lainnya.

Ketiga unsur seperti dosen, mahasiswa dan kurikulum saling berkaitan. Kurikulum mencerminkan capaian mahasiswa yang memiliki kompetensi di bidang tertentu sehingga lulusan menjadi siap pakai di dunia kerja. Dua unsur di atas akan tercapai jika didukung oleh tenaga dosen yang benar-benar memiliki ilmu yang dapat ditransfer kepada mahasiswanya sesuai dengan kebutuhan dunia kerja. Berikut ini beberapa petunjuk yang dapat menjadi pertimbangan dalam menjalankan Kurikulum Merdeka Belajar.

\section{$5.1 \quad$ Kurikulum}

Kurikulum hendaknya dirancang sesuai dengan kebutuhan pasar. Kebutuhan pasar beragam, yang mana yang dipilih? Pemilihan disesuaikan dengan ketersediaan tenaga dosen serta bidang keahlian dosen yang ada. Kurikulum harus mencerminkan CP dari setiap mata kuliah yang akan mengerucut kepada CP akhir dari lulusan. CP mata kuliah sebaiknya selalu mengarah kepada $\mathrm{CP}$ akhir agar tetap terarah.

Bagaimana mengetahui perusahaan jenis apa menjadi pemakai jasa para lulusan? Disini harus tetap terjalin hubungan antara prodi dengan alumni dan perusahaan yang menjadi mitrakerjanya. Untuk mengetahui kebutuhan pasar, sebaiknya dilakukan tracer study yang melibatkan lulusan, mitrakerja, mahasiswa. Dari hasil tracer study terhadap mahasiswa dapat diketahui persentase mata kuliah yang dianggapnya berguna untuk diterapkan saat bekerja. Jika sebagian besar mahasiswa berpendapat mata kuliah tertentu tidak memberi manfaat untuk bekerja-sekalipun prodi menganggap mata kuliah itu sebagai keunggulannya-prodi terpaksa menyingkirkannya karena lebih mementingkan minat mahasiswa.

Dengan demikian, prodi harus bersikap jujur terhadap hasil tracer study. Dari hasil itu ditetapkan visi misi, tujuan dan CP lulusan yang disesuaikan dengan keahlian tenaga dosen yang ada. Walaupun satu bidang keahlian ditawarkan prodi, tetapi mendalam, dapat menjadi keunggulan prodi tersebut.

Untuk menghindarkan kebingungan prodi bidang apa yang menjadi kekhususannya, hendaknya prodi menentukan jenis perusahaan mitrakerja yang mana yang akan disurvei. Perusahaan yang sering "memesan" mahasiswa untuk magang di perusahaannya atau banyak lulusan bekerja di sebuah perusahaan/instansi merupakan salah satu alternatif tempat melakukan survei. Biasanya perusahaan pemakai jasa lulusan berasal dari Tiongkok, Taiwan, Singapura dan Malaysia. Jenis perusahaannya antara lain, ponsel, komputer, tambang, otomotif, alat-alat kesehatan, alat rumah tangga, garmen, aksesori, mainan anakanak, dan sebagainya. Jenis instansi yang banyak menggunakan lulusan prodi Cina antara lain kementerian-kementerian RI, kedutaan RRT, Teto, PT, kursus dan sebagainya.

Setelah mendapatkan hasil dari tracer study, prodi mulai merancang kurikulum dengan berpedoman pada bidang tertentu sesuai dengan hasil di atas. Penyusunan dilakukan dengan menentukan CP lulusan prodi dan jenis pekerjaannya, seperti sekretaris, penerjemah (translator), juru bahasa (interpreter), pemandu wisata, peneliti tingkat awal, 
guru, dan sebagainya. Langkah selanjutnya, mulai menentukan jenis mata kuliah, mana yang MK universitas, mana MK fakultas. Jumlah sks dari kedua MK itu sudah ditentukan oleh Kemenristek. Kemudian para perancang kurikulum menentukan MK wajib prodi yang akan menjadi bidang keahlian lulusan. Selanjutnya menentukan MK lintas prodi, MK lintas universitas dan magang yang akan memperkuat CP MK wajib prodi.

\subsection{Dosen dan Mahasiswa}

Pembicaraan kedua unsur ini disatukan mengingat keduanya membutuhkan kerja sama yang baik demi tercapainya CP. Baik dosen maupun mahasiswa harus melek digital. Pada umumnya mahasiswa lebih piawai menggunakan program-program yang ada di komputer serta berselancar di internet, karena mereka sudah mempelajarinya paling kurang sejak SMP.

Bagaimana dengan dosen? Kemampuan dosen menggunakan program secara digital bervariasi. Di masa pandemi ini bermunculan pelbagai program aplikasi pengajaran bahasa secara daring. Hal ini termasuk disrupsi pada era industri 4.0 ini yang merupakan tantangan bagi dosen untuk mengikuti perkembangan teknologi digital. Selain itu, dosen harus akrab dengan internet agar (1) tidak bisa diperdaya oleh mahasiswa yang lebih pandai membuka tautan di internet (2) memperluas ilmu dan pengetahuan umum melalui internet karena sebagian besar informasi disebarkan melalui internet (3) mengetahui topik-topik yang sudah ditulis oleh mahasiswa atau dosen dari PT lain guna menghindari plagiarisme (4) mengetahui sumber mana yang ilmiah dan mana yang tidak ilmiah yang bertebaran di situssitus internet. Hendaknya dosen sadar bahwa ada mahasiswa tidak jujur yang selalu mencari kelemahan dosen demi keuntungan dirinya.

Sehubungan dengan tujuan PT menghasilkan lulusan yang siap guna di masyarakat, PT harus mengalihkan metode pembelajaran dari yang berpusat pada dosen (teacher oriented) kepada yang berpusat pada mahasiswa (student oriented). Jika sebelumnya dosen selalu berceramah, mahasiswa mendengar dan mencatat setelah itu baru ada tanya jawab, maka sekarang mahasiswa dituntun untuk menemukan sendiri permasalahan serta mencari jawabannya. Atau, dosen melemparkan masalah, mahasiswa mencari jawaban dengan berdasarkan teori yang dipelajari. Pembelajaran model ini membutuhkan kerja sama di antara mahasiswa. Di sinilah dilatih kerja sama antarmereka yang merupakan praktek sebelum bekerja secara nyata di kantor, perusahaaan, instansi, PT atau tempat kerja lainnya. Kerja kelompok menjadi medan praktek bersosialisasi sebelum terjun ke masyarakat. Di sini dibutuhkan softskill seperti kesantunan, empati, memupuk rasa tolong menolong sejati dengan menerapkan budaya Indonesia sebagai orang Timur terhadap sesama orang Indonesia dan orang asing. Masing-masing harus tahu posisinya sebagai apa di dalam kelompoknya, bagaimana ketua harus bersikap terhadap anggota kelompoknya, begitu pula sebaliknya. PT tidak hanya memberikan hardskills saja, tetapi juga softskills, sehingga lulusan dapat berinteraksi dengan perilaku santun terhadap teman kerja dan atasan.

\section{F. PENUTUP}

Implementasi Kurikulum Merdeka Belajar yang ditetapkan Pemerintah merupakan jawaban terhadap kemajuan dunia di bidang teknologi informasi. Disrupsi terjadi di dunia PT, tetapi disrupsi tidak dipandang sebagai hal yang mematikan, melainkan sebagai tantangan yang harus dihadapi yang membawa perubahan dan perbaikan terhadap kekurangan yang 
ada selama ini. Untuk mencapainya, semua unsur PT harus bekerja sama dan bertekad untuk maju mengikuti perkembangan dunia pendidikan internasional.

Tantangan terberat dihadapi program studi Mandarin/Tiongkok/Sinologi yang $90 \%$ mahasiswanya tidak bisa berbahasa Mandarin saat memasuki PT, tetapi dalam delapan semester sudah harus kompeten berbahasa Mandarin lisan dan tulis untuk digunakan sebagai alat komunikasi dalam bekerja. Perancang kurikulum harus sangat cermat menentukan tingkat kompetensi lulusannya agar siap pakai di dunia kerja.

\section{DAFTAR PUSTAKA}

[1] Buku Saku Panduan Merdeka Belajar Kampus Merdeka, dikeluarkan oleh Direktorat Jendral Pendidikan Tinggi Kementerian Pendidikan dan Kebudayaan, tahun 2020.

[2] Faddillah, Umi. 2020. "Pandemi Covid-19 dan Era Society 5.0" dalam Republika.co.id. Jumat 10 April 2020 pk. 05.16 WIB.

[3] Faulinda Ely Nastiti, Aghni Rizqi Ni'mal 'Abdu. 2020. "Kesiapan Pendidikan Indonesia menghadapi era society 5.0" dalam Jurnal Kajian Teknologi Pendidikan. Surakarta: Fakultas Ilmu Komputer Universitas Duta Bangsa Surakarta, vol 5, no.1v April 20, 61-66 Edcomtech. pISSn 2548-9879. elssn 2599-2139

[4] Helmi, Nasrul. 2019. "Revolusi Industri 4.0 dan Pengaruhnya bagi Industri di Indonesia". Kementerian Pertahanan RI. 30 April 2019.

[5] Pendidikan Berbasis Capaian Pembelajaran (Outcome-based Education/OBE), dikeluarkan oleh Direktorat Penjaminan Mutu DITJEN BELMAWA KEMENRISTEKDIKTI.

[6] Sutami, Hermina. 2019. Seminar Potensi Kajian Bahasa dan Budaya Tiongkok di Era Revolusi Indonesia 4.0, Universitas Gunadarma, 4 Februari 2019, PPT, narasumber.

[7] https://www.puskomedia.id/masyarakat-5-0 diunduh 18 Oktober 2020

[8] https://properti.kompas.com/read/2019/01/25/213000921/jepang-menjelang-5.0society-dan-era-menikmati-hidup?page=all 